\title{
Kajian Keputusan Pembelian Konsumen Produk Kecantikan Merek Oriflame Di Yogyakarta
}

\author{
Juni Trisnowati ${ }^{1}$, Renza Dian Nur Indah Sari ${ }^{2)}$ \\ ${ }^{1,2}$ Fakultas Ekonomi Universitas Surakarta \\ E-mail: ${ }^{1)}$ junitrisnowati@gmail.com ${ }^{2)}$ renzahaha@gmail.com
}

\begin{abstract}
ABSTRAK
Penelitian ini bertujuan untuk menganalisis faktor-faktor yang mempengaruhi keputusan pembelian konsumen atas produk kecantikan merek Oriflame di Yogyakarta. Faktor-faktor yang dikaji dalam penelitian ini adalah citra merek, promosi, dan harga. Populasi dalam penelitian ini adalah konsumen produk kecantikan merek Oriflame di Yogyakarta, dimana jumlahnya tidak diketahui secara pasti. Metode pengambilan sampel yang digunakan adalah accidental sampling, dengan jumlah sampel 100 responden. Jenis data merupakan data primer, dimana metode pengumpulan datanya menggunakan kuesioner. Analisis data yang digunakan dalam penelitian ini adalah analisis regresi linier berganda, uji F, uji t, dan koefisien determinasi. Hasil analisis data dalam penelitian ini menyatakan bahwa citra merek $\left(\mathrm{X}_{1}\right)$ berpengaruh signifikan terhadap keputusan pembelian $(\mathrm{Y})$, promosi $\left(\mathrm{X}_{2}\right)$ berpengaruh signifikan terhadap keputusan pembelian $(\mathrm{Y})$, dan harga $\left(\mathrm{X}_{3}\right)$ berpengaruh signifikan. tentang keputusan pembelian (Y). Secara simultan citra merek $\left(\mathrm{X}_{1}\right)$, promosi $\left(\mathrm{X}_{2}\right)$, dan harga $\left(\mathrm{X}_{3}\right)$ berpengaruh signifikan terhadap keputusan pembelian (Y). Koefisien determinasi $\left(\mathrm{R}^{2}\right)$ sebesar 0,824 yang artinya variabel bebas yang terdiri dari citra merek, promosi, dan harga berpengaruh terhadap keputusan pembelian produk Oriflame sebesar 82,4\%, sedangkan sisanya 17,6\% dipengaruhi oleh faktor lain.

Kata kunci: citra merek, promosi, harga, dan keputusan pembelian.
\end{abstract}

\begin{abstract}
This study aims to analyze the factors that influence consumer purchasing decisions for the Oriflame brand beauty products in Yogyakarta. The factors examined in this study are brand image, promotion, and price. The population in this study were the consumers of the Oriflame brand beauty products in Yogyakarta, where the exact number is not known. The sampling method used was accidental sampling, with a sample size of 100 respondents. The type of data is primary data, where the data collection method uses a questionnaire. Data analysis used in this research is multiple linear regression analysis, $\mathrm{F}$ test, $\mathrm{t}$ test, and the coefficient of determination. The results of data analysis in this study state that brand image $\left(\mathrm{X}_{1}\right)$ has a significant effect on purchase decisions $(\mathrm{Y})$, promotion $\left(\mathrm{X}_{2}\right)$ has a significant effect on purchasing decisions $(\mathrm{Y})$, and price $\left(\mathrm{X}_{3}\right)$ has a significant effect. about the purchase decision $(\mathrm{Y})$. Simultaneously, brand image $\left(\mathrm{X}_{1}\right)$, promotion $\left(\mathrm{X}_{2}\right)$, and price $\left(\mathrm{X}_{3}\right)$ have a significant effect on purchasing decisions $(\mathrm{Y})$. The coefficient of determination $\left(\mathrm{R}^{2}\right)$ is 0.824 , which means that the independent variables consisting of brand image, promotion, and price have an effect on purchasing decisions for Oriflame products by $82.4 \%$, while the remaining $17.6 \%$ is influenced by other factors.
\end{abstract}

Keywords: brand image, promotion, price, and purchase decision.

\section{PENDAHULUAN}

Dunia bisnis mengalami perubahan secara terus menerus, seiring dengan perkembangan dalam teknologi informasi dan gaya hidup masyarakat. Jumlah produk yang tersedia di masyarakat semakin beragam, sehingga konsumen mempunyai banyak pilihan produk yang dapat memenuhi kebutuhannya sesuai yang mereka inginkan. Dan menjadi suatu keharusan bagi perusahaan untuk memahami faktor apa saja yang dapat mempengaruhi keputusan pembelian, mengingat persaingan dalam dunia bisnis semakin ketat.

Menurut Herlambang (2014) keputusan pembelian merupakan suatu keputusan sebagai pemilikan suatu tindakan dari dua atau lebih pilihan alternatif. Dalam melakukan evaluasi alternatif, konsumen akan mengembangkan sebuah keyakinan atas merek dan tentang posisi tiap merek berdasarkan masing-masing atribut yang berujung pada pembentukan citra merek. Apakah produk yang akan dibeli sudah sesuai dengan kebutuhan atau keinginannya. Kemudian produk yang akan dibeli tersebut apakah sudah sesuai dengan kondisi dirinya, seperti biaya yang dibutuhkan untuk mendapatkan suatu produk yang diinginkan. Sebelum membeli, konsumen terlebih dahulu akan melakukan beberapa alternatif pilihan, apakah akan membeli atau tidak. 
Ada beberapa hal yang bisa dilakukan oleh perusahaan untuk mempengaruhi keputusan pembelian dari konsumen, seperti melakukan pengembangan produk yang berkualitas untuk membentuk citra merek di benak konsumen, pemberian harga yang kompetitif, dan juga melaksanakan kegiatan promosi yang efektif. Studi mengenai perilaku pembelian konsumen bagi suatu perusahaan sudah seharusnya dilakukan, mengingat bahwa dengan pemahaman yang baik tentang keputusan pembelian dapat memberikan kemudahan bagi perusahaan untuk merencanakan strategi pemasaran agar sesuai dengan apa yang diharapkan oleh konsumen dan mendorong konsumen untuk melakukan pembelian. Disamping itu dengan memahami perilaku pembelian konsumen, perusahaan bisa mengidentifikasi faktor-faktor apa yang dapat dikendalikan perusahaan yang dapat digunakan untuk mendorong konsumen melakukan pembelian produknya.

Penelitian terdahulu yang telah dilakukan oleh Sari Devi Puspita, dkk (2018), menyatakan bahwa secara signifikan variabel citra merek, kualitas produk dan harga berpengaruh terhadap keputusan pembelian. Penelitian lain yang sejalan dilakukan oleh Fure Ferdyanto, dkk (2015), dengan hasil bahwa brand image, kualitas produk dan harga secara simultan berpengaruh signifikan terhadap keputusan pembelian, namun harga secara parsial tidak berpengaruh signifikan terhadap keputusan pembelian. Penelitian yang dilakukan oleh Shinta Devy, dkk (2019), mengungkapkan hasil berupa variabel harga berpengaruh positif dan signifikan terhadap keputusan pembelian, dan variabel promosi tidak berpengaruh signifikan terhadap keputusan pembelian. Berbeda dengan penelitian Shinta Devy, hasil penelitian Permana Dony Indra menyatakan bahwa variabel promosi memiliki pengaruh signifikan terhadap variabel keputusan pembelian konsumen. Hasil penelitian Sutrisno (2018) menyatakan bahwa bauran pemasaran memiliki pengaruh signifikan terhadap keputusan pembelian. Dan bauran pemasaran yang dimaksud mencakup produk, harga, tempat, dan promosi. Penelitian yang dilakukan Fure Ferdyanto, dkk (2015), Zulaicha Santri dan Irawati Rusda (2016), Sari Devi Puspita, dkk (2018), Devy Shinta, dkk (2019), mengungkapkan hasil berupa pentingnya harga dalam mempengaruhi keputusan pembelian yang dilakukan oleh konsumen.

Citra merek adalah kreasi yang diciptakan oleh program pemasaran yang memiliki link yang sangat menguntungkan, dan asosiasi yang unik yang tertanam dalam memori konsumen (Kotler, 2008). Sangadji dan Sopiah (2013) mengatakan bahwa citra merek dapat positif maupun negatif, tergantung pada presepsi seseorang terhadap merek.

Faktor yang tidak kalah pentingnya dalam perilaku pembelian konsumen adalah promosi. Promosi merupakan suatu cara memperkenalkan, mengkomunikasikan manfaat dari sebuah produk atau jasa dan konsumen untuk menggunakan produk yang ditawarkan. Cara promosi dapat dilakukan melalui media sosial, pembicaraan, katalog, dan lain-lain. Promosi merupakan kegiatan yang ditunjukkan untuk mempengaruhi konsumen agar mereka dapat menjadi kenal akan produk yang ditawarkan oleh perusahaan kepada mereka dan kemudian menjadi senang lalu membeli produk tersebut.

Keputusan pembelian merupakan suatu keputusan konsumen yang dipengaruhi oleh ekonomi keuangan, teknologi, politik, budaya, produk, harga, lokasi, promosi, physical evidence, people, dan process, sehingga membentuk suatu sikap pada konsumen untuk mengolah segala informasi dan mengambil kesimpulan berupa respon yang muncul, produk apa yang akan dibeli (Alma, 2016). Menurut Setiadi (2010) keputusan pembelian merupakan proses pengintegrasian yang mengkombinasikan pengetahuan untuk mengevaluasi dua atau lebih perilaku alternatif dan memilih salah satu diantaranya.

Menurut Kotler \& Amstrong (2008) keputusan pembelian adalah keputusan pembeli tentang merek mana yang dibeli. Pengertian lain keputusan pembelian adalah keputusan konsumen mengenai preferensi atas merek-merek yang ada di dalam kumpulan pilihan (Kotler \& Keller, 2012). Jadi keputusan pembelian yaitu perilaku konsumen dalam memilih salah satu merek dari banyaknya merek yang ada.

Keputusan konsumen untuk membeli produk atau jasa merupakan potensi pemecahan atas pemenuhan kebutuhan dan pemenuhan keinginan mereka yang belum atau tidak terpenuhi. Dalam melakukan pembelian berbagai konsumen membeli barang-barang yang berbeda yang disebabkan perbedaan karakteristik pribadi (kebutuhan, manfaat yang dicari, sikap, nilai, pengalaman masa lalu dan gaya hidup) dan pengaruh sosial (perbedaan kelas sosial, kelompok rujukan, atau kondisi keluarga).

Perilaku pembelian dapat menyebabkan suatu pemecahan masalah yang berbeda bagi tiap individu dan bukan sebagai suatu persamaan. Oleh karena itu semakin banyak pengetahuan yang dimiliki pemasar tentang faktor-faktor yang mempengaruhi perilaku konsumen mereka, maka akan semakin besar kemampuan mereka untuk mendesain penawaran produk dan jasa yang menarik, mengenali dan mentargetkan segmen-segmen pasar yang berarti dan mengembangkan program-program bauran pemasaran yang sesuai dengan keinginan khusus dari segmen tersebut. 
Untuk meraih keberhasilan, pemasar harus memahami bermacam-macam pengaruh yang mempengaruhi pembeli dan mengembangkan pemahaman mengenai konsumen melakukan keputusan pembeli. Secara khusus pemasar harus mengidentifikasi siapa yang membuat keputusan pembelian, jenisjenis keputusan pembelian dan langkah-langkah dalam proses pembelian. Indikator keputusan pembelian dalam penelitian ini adalah:

1) Pilihan produk

2) Pilihan merek

3) Pilihan member

4) Waktu pembelian

5) Jumlah pembelian.

Menurut Kotler (2009) merek merupakan sebuah nama, istilah, tanda, simbol, atau desain atau kombinasi dari keseluruhannya yang bertujuan untuk mengidentifikasi barang-barang maupun jasa dari suatu kelompok penjual dan untuk membedakan produk mereka dari para pesaing. Citra merek merupakan persepsi keseluruhan merek dan dibentuk berdasarkan kesimpulan konsumen membentuk suatu merek, baik berdasarkan rangsangan eksternal maupun khayalan mereka (Assael, 2001).

Menurut Sangadji (2013) citra merek dapat dianggap sebagai jenis asosiasi yang muncul di benak konsumen ketika mengingat sebuah merek tertentu. Asosiasi tersebut secara sederhana dapat muncul dalam bentuk pemikiran atau citra tertentu yang dikaitkan dengan suatu merek, sama halnya ketika kita berfikir mengenai orang lain.

Menurut Kotler \& Keller (2012) citra merek adalah proses dimana seseorang memilih, mengorganisasikan, dan mengartikan masukan informasi untuk menciptakan suatu gambaran yang berarti. Citra merek menggambarkan ekstrinsik produk atau jasa, termasuk cara dimana mereka berusaha memenuhi kebutuhan psikologis atau sosial pelanggan. Agar citra yang benar dapat tertanam dalam pikiran konsumen, pemasar harus memperhatikan identitas merek melalui semua sarana komunikasi dan kontak merek yang tersedia. Citra merek dalam benak konsumen dapat bersifat positif atau negatif, tergantung pada persepsi seseorang terhadap merek.

Menurut Aaker (2009) dalam Sari D.P. (2018), indikator dari citra merek adalah:

1) Product attributes (atribut produk)

2) Consumer benefits (keuntungan konsumen)

3) Brand personality (kepribadian merek).

Promosi adalah salah satu variabel dalam bauran pemasaran yang sangat penting dilaksanakan oleh perusahaan dalam memasarkan produk. Promosi adalah semua jenis kegiatan pemasaran yang ditujukan untuk mendorong permintaan. Promosi adalah arus informasi atau persuasi satu arah yang dibuat untuk mengarahkan seseorang atau organisasi pada tindakan yang menciptakan pertukaran dalam pemasaran (Tjiptono, 2008). Promosi adalah semua jenis kegiatan pemasaran yang ditujukan untuk mendorong permintaan (Haryono, 2012).

Promosi merupakan informasi atau persuasi salah satu arah yang dibuat untuk mengarahkan seseorang atau organisasi kepada tindakan yang menciptakan pertukaran dalam pemasaran (Swastha, 2013). Perusahaan harus mengadakan komunikasi dengan konsumen untuk membantu perusahaan dalam mengambil keputusan pemasaran dan mengarahkan informasi antara pihak konsumen dengan perusahaan. Sehingga dapat disimpulkan bahwa promosi mempunyai fungsi yang utama yaitu komunikasi yang baik dari produsen ke konsumen juga sebaliknya. Promosi merupakan usaha menarik konsumen untuk datang ke tokonya, promosi yang baik akan sangat mempengaruhi pembeli.

Tujuan utama dari promosi adalah menginformasikan, mempengaruhi, dan membujuk, serta meningkatkan pelanggan sasaran tentang perusahaan dan bauran pemasarannya (Tjiptono, 2008). Dari definisi diatas dapat disimpulkan bahwa promosi adalah kegiatan untuk menarik agar calon pembeli mau melakukan transaksi dengan penjual sehingga tujuan dari perusahaan untuk mendapatkan laba dapat tercapai. Menurut Haryono (2012), komponen dalam strategi promosi mencakup:

1) Iklan

2) Penjualan Langsung

3) Promosi Penjualan

4) Publisitas.

Harga yang kompetitif membawa pengaruh terhadap keputusan pembelian oleh konsumen. Menurut Tjiptono (2008),harga adalah sejumlah uang dan jasa atau barang-barang yang tersedia ditukarkan pembeli untuk mendapatkan berbagai pilihan produk-produk dan jasa-jasa yang disediakan penjual. Harga adalah 
jumlah uang (kemungkinan ditambah beberapa barang) yang dibutuhkan untuk memperoleh beberapa kombinasi sebuah produk dan pelayanan yang menyertainya. Indikator dari harga menurut Kotler (2009) adalah:

1) Keterjangkauan harga

2) Kesesuaian harga dengan kualitas produk

3) Daya saing harga

4) Kesesuaian harga dengan manfaat.

Kurniawan F., Arifin Z. \& Fanani D. (2018), menjelaskan adanya pengaruh citra merek terhadap keputusan pembelian (survei kepada para siswa SMAN 15 Surabaya Kelas XII yang menggunakan laptop bermerek Asus). Penelitian yang dilakukan oleh Sari D.P. \& Nuvriasari A. (2018), F.Fure, J. Lapan \& R Taroreh (2015), dan Susanti I.Y., Tjahyono E. \& Nasution U.Ch. (2015) menunjukkan bahwa citra merek berpengaruh signifikan terhadap keputusan pembelian. Penelitian Khasanah A.S.N. (2017), salah satu hasilnya menyatakan bahwa ada pengaruh positif dan signifikan antara citra merek terhadap minat beli produk Oriflame. Hasil Penelitian Ahmad M., dkk (2020) memberikan kesimpulan bahwa citra merek berpengaruh terhadap minat beli.

Hasil penelitian yang dilakukan oleh Permana D.I. (2017), menjelaskan ada pengaruh promosi terhadap keputusan pembelian produk lantai kayu dan pintu PT. Piji di Jawa Timur. Penelitian lain yang dilakukan oleh Devy S. \& Sinulingga, N.A.B. (2019), Wulandari P.P. \& Widayanto (2020), menunjukkan bahwa promosi berpengaruh signifikan terhadap keputusan pembelian.

Hasil penelitian yang dilakukan oleh Utomo, L.B., Trisnowati, J. (2017), menjelaskan bahwa ada pengaruh harga terhadap Keputusan Pembeli pada Toko Alfamart Mojolaban Sukoharjo. Penelitian lain yang dilakukan Zulaicha S. \& Irawati R (2016), Sutrisno N.A.R.A., Widodo J. \& Zulianto M. (2018) menunjukkan bahwa harga berpengaruh signifikan terhadap keputusan pembelian.

Kosmetika merupakan salah satu kebutuhan sehari-hari yang harus dipenuhi khususnya bagi para wanita. Banyak perusahaan kosmetika yang ada di pasaran, yang menawarkan berbagai jenis produk. Oriflame merupakan salah satu perusahaan kosmetika yang berbasis MLM (Multi Level Marketing) yang bermula di Stockholm, Sweden, tahun 1967 oleh dua orang bersaudara Jonas dan Robert af Jochnick. Oriflame hadir di Indonesia pada tahun 1986 di bawah naungan PT. Orindo Alam Ayu. Sejak berada di Indonesia, Oriflame sudah banyak menerima penghargaan, salah satunya adalah penghargaan yang dianugerahkan oleh Haper's Bazaar Beauty Awards 2007. Selain penghargaan yang diberikan oleh Haper's Bazaar Beauty Awards, Oriflame juga mendapat penghargaan sebagai Indonesia Most Favorite Youth Brand pada tahun 2011 yang diselenggarakan oleh majalah Marketeers dan Mark Plus Insight untuk kategori Blush On, Mascara dan Eye Shadow. Oriflame memiliki kantor penjualan di 59 negara dan merupakan pemimpin pasar di lebih dari 30 negara. Jaringan penjualan yang terdiri dari 1,8 juta konsultan mandiri yang memasarkan rangkaian lengkap perawatan kulit, wewangian, dan kosmetik.

Persaingan yang ada diantara perusahaan kosmetika menuntut perusahaan untuk memahami perilaku pembelian dari konsumennya. Banyak faktor yang menjadi pertimbangan konsumen dalam melakukan pembelian, misalnya harga produk, promosi yang dilakukan perusahaan, citra merek dari suatu produk, dan lain-lain. Untuk itu, perusahaan perlu memahami faktor-faktor apa saja yang mendorong konsumen untuk melakukan pembelian terhadap produk perusahaan.

Tujuan penelitian ini adalah untuk menganalisis pengaruh citra merek, promosi dan harga terhadap keputusan pembelian konsumen produk kecantikan merek Oriflame di Yogyakarta, baik secara parsial maupun secara simultan.

\section{METODE PENELITIAN}

Penelitian ini merupakan penelitian kuantitatif dengan menggunakan metode survai, dimana populasinya adalah keseluruhan konsumen produk kecantikan merek Oriflame di Yogyakarta yang jumlahnya tidak dapat diketahui secara pasti. Metode sampling yang digunakan adalah accidental sampling dengan jumlah sampel sebanyak 100 responden. Teknik pengumpulan data dilakukan dengan wawancara terstruktur dan kuesioner yang bersifat tertutup dengan alternatif jawabannya menggunakan skala Likert. Uji instrumen yang dilakukan adalah uji validitas dan uji reliabilitas. Analisis data yang digunakan adalah regresi linier berganda, uji F, uji t, dan koefisien determinasi $\left(\mathrm{R}^{2}\right)$. 


\section{HASIL PENELITIAN}

\section{Uji Instrumen}

Uji validitas instrumen dilakukan dengan menggunakan rumus Korelasi Product Moment. Suatu butir pertanyaan dinyatakan valid jika $\mathrm{r}_{\text {hitung }}$ lebih besar dari $\mathrm{r}_{\text {tabel. }}$. Semua butir pertanyaan yang digunakan dalam penelitian ini dinyatakan valid karena $\mathrm{r}_{\text {hitung }}$ lebih besar dari $\mathrm{r}_{\text {tabel. }}$

Uji reliabilitas ini dilakukan dengan menggunakan rumus Alpha Cronbach. Kriteria pengujian dilakukan dengan membandingkan nilai Alpha Cronbach dengan nilai kritis sebesar 0,60. Apabila nilai Alpha Cronbach dari setiap intrumen variabel lebih besar dari 0,60 maka butir pertanyaan dinyatakan reliabel. Semua butir pertanyaan yang digunakan dalam penelitian ini dinyatakan reliabel karena nilai Alpha Cronbach lebih besar dari 0,60

\section{Regresi Linier Berganda}

Dengan menggunakan program SPSS diperoleh hasil print out sebagai berikut:

Tabel 1. Hasil Uji Persamaan Regresi

Coefficients $^{\mathrm{a}}$

\begin{tabular}{|c|c|c|c|c|c|}
\hline \multirow[b]{2}{*}{ Model } & \multicolumn{2}{|c|}{$\begin{array}{c}\text { Unstandardized } \\
\text { Coefficients }\end{array}$} & \multirow{2}{*}{$\begin{array}{c}\begin{array}{c}\text { Standardize } \\
\mathrm{d} \\
\text { Coefficients }\end{array} \\
\text { Beta } \\
\end{array}$} & \multirow[b]{2}{*}{$\mathrm{t}$} & \multirow[b]{2}{*}{ Sig. } \\
\hline & B & Std. Error & & & \\
\hline (Constant) & 2.295 & .740 & & 3.103 & .003 \\
\hline TOTAL.X1 & .200 & .076 & .228 & 2.642 & .010 \\
\hline TOTAL.X2 & .592 & .078 & .624 & 7.609 & .000 \\
\hline TOTAL.X3 & .089 & .043 & .120 & 2.077 & .040 \\
\hline
\end{tabular}

a. Dependent Variable: TOTAL.Y

Berdasarkan tabel diatas, diperoleh persamaan regresi sebagai berikut: $\mathrm{Y}=2,295+0,200 \mathrm{X} 1+0,592 \mathrm{X} 2$ $+0,089 \mathrm{X} 3$

\section{Uji Hipotesis Simultan (Uji F)}

Tabel 2. Hasil Uji F

\begin{tabular}{|rl|r|r|r|r|r|}
\hline \multicolumn{1}{|c|}{ ANOVA $^{\mathrm{a}}$} \\
\hline & Model & Sum of & & & \\
\hline & Squares & Df & Mean Square & F & \multicolumn{1}{c|}{ Sig. } \\
\hline & Regression & 345.651 & 3 & 115.217 & 149.351 & $.000^{\mathrm{b}}$ \\
& Residual & 74.059 & 96 & .771 & & \\
& Total & 419.710 & 99 & & & \\
\hline
\end{tabular}

a. Dependent Variable: TOTAL.Y

b. Predictors: (Constant), TOTAL.X3, TOTAL.X2, TOTAL.X1

Pada level of signifikansi $\mathrm{a}=0,05 ; \mathrm{df}$ (degress of freedom $)=(\mathrm{k} ; \mathrm{n}-\mathrm{k}-1)$, maka diperoleh nilai $\mathrm{F}$ tabel sebesar 2,700.Karena $F$ hitung $>F$ tabel yaitu 149,351 > 2,700 dan p-value sebesar 0,000 lebih kecil dari 0,05, berarti Ho ditolak dan Ha diterima. Artinya citra merek, promosi, dan harga secara simultan berpengaruh signifikan terhadap keputusan pembelian produk Oriflame di Yogyakarta.

\section{Uji Hipotesis Parsial (Uji t)}

Pengaruh citra merek $\left(\mathrm{X}_{1}\right)$ terhadap keputusan pembelian produk kecantikan merek Oriflame (Y)

Berdasarkan tabel 1 diperoleh $t_{\text {hitung }}$ sebesar 2,642. Pada level of signifikansi $\alpha=0,05$; df (degrees of freedom $)=\mathrm{n}-\mathrm{k}-1$, diperoleh $\mathrm{t}_{\text {tabel }}$ sebesar 1,984 . Karena $\mathrm{t}_{\text {.hitung }}>\mathrm{t}_{\text {tabel }}(2,642>1,984)$ dan $\mathrm{p}$-value 0,010 lebih kecil dari 0,05, berarti Ho ditolak dan Ha diterima. Artinya citra merek berpengaruh signifikan terhadap keputusan pembelian produk kecantikan merek Oriflame. Dari hasil kuesioner yang telah dikumpulkan dijelaskan bahwa merek Oriflame sudah dikenal banyak orang, produk Oriflame sangat cocok bagi masyarakat Indonesia yang beriklim tropis, jawaban dari responden tergolong sangat tinggi. 


\section{Pengaruh promosi $\left(\mathrm{X}_{2}\right)$ terhadap keputusan pembelian produk kecantikan merek Oriflame (Y)}

Berdasarkan hasil olah data yang disajikan pada tabel 1 menyimpulkan bahwa $t_{\text {.hitung }}>t_{\text {.tabel }}(7,609>$ 1,984) dan p-value 0,000 lebih kecil dari 0,05 , berarti Ho ditolak dan Ha diterima. Artinya promosi berpengaruh signifikan terhadap keputusan pembelian produk kecantikan merek Oriflame. Dari hasil kuesioner yang telah dikumpulkan jawaban responden tergolong sangat tinggi untuk pertanyaan Oriflame mengadakan event-event kecantikan untuk memperkenalkan produknya, member memberikan diskon pada pembelian produknya yang membeli melalui penjualan umum.

\section{Pengaruh harga $\left(\mathbf{X}_{3}\right)$ terhadap keputusan pembelian produk kecantikan merek Oriflame (Y)}

Berdasarkan tabel 1 diperoleh nilai $t$ hitung sebesar 2,077. Karena $t_{\text {.hitung }}$ lebih besar dari $t$.tabel $(2,077>$ 1,984) dan p-value 0,040 lebih besar dari 0,05, berarti Ho ditolak dan Ha diterima. Artinya harga berpengaruh signifikan terhadap keputusan pembelian produk kecantikan merek Oriflame di Yogyakarta. Dari hasil kuesioner yang telah dikumpulkan dijelaskan bahwa harga produk Oriflame terjangkau, harga produk Oriflame lebih murah dibanding dengan produk impor lainnya, jawaban responden tergolong sangat tinggi.

\section{Koefisien Determinasi $\left(\mathbf{R}^{2}\right)$}

Dari hasil analisis data diperoleh nilai Koefisien Determinasi $\left(\mathrm{R}^{2}\right)$ sebagai berikut:

Tabel 3. Hasil Uji Koefisien Determinasi

\begin{tabular}{|c|c|r|c|c|}
\hline Model & R & R Square & $\begin{array}{c}\text { Adjusted R } \\
\text { Square }\end{array}$ & $\begin{array}{c}\text { Std. Error of } \\
\text { the Estimate }\end{array}$ \\
\hline 1 & $.907^{\mathrm{a}}$ & .824 & .818 & .878 \\
\hline
\end{tabular}

a. Predictors: (Constant), TOTAL.X3, TOTAL.X2, TOTAL.X1

Berdasarkan tabel di atas, nilai adjusted $R$ Square $\left(\mathrm{R}^{2}\right)$ sebesar 0,824 , artinya bahwa variabel-variabel independen yang terdiri dari citra merek, promosi, dan harga berpengaruh terhadap keputusan pembelian produk Oriflame di Yogyakarta sebesar 0,824 atau 82,4\% sedangkan sisanya sebesar 17,6\% dipengaruhi oleh faktor lainnya. Hasil ini menunjukkan bahwa pemilihan variabel-variabel yang mempengaruhi keputusan pembelian sudah tepat, mengingat nilai koefisien determinasi dalam penelitian ini relatif besar, namun demikian masih terdapat variabel lain yang dapat digunakan untuk menganalisis penentu keputusan pembelian.

\section{PEMBAHASAN}

1. Citra merek berpengaruh signifikan terhadap keputusan pembelian produk kecantikan merek Oriflame di Yogyakarta

Hasil penelitian ini mendukung penelitian Susanti, Tjahyono dan Nasution (2015), Khasanah (2017), Arifin dan Fanani (2018), Sari dan Nuvriasari (2018), serta Ahmad (2020) bahwa citra merek berpengaruh signifikan terhadap keputusan pembelian. Hal ini berarti bahwa semakin melekat citra merek Oriflame di benak konsumen, maka akan meningkatkan keputusan pembelian terhadap produk kecantikan merek Oriflame.

2. Promosi berpengaruh signifikan terhadap keputusan pembelian produk kecantikan merek Oriflame di Yogyakarta.

Hasil penelitian ini mendukung penelitian Permana (2017), Devy dan Sinulingga (2019), Wulandari dan Widayanto (2020) bahwa promosi berpengaruh signifikan terhadap keputusan pembelian. Hal ini berarti semakin banyak kegiatan promosi yang dilakukan (misalnya event-event kecantikan), maka akan mendorong konsumen untuk melakukan pembelian produk kecantikan merek Oriflame.

3. Harga berpengaruh signifikan terhadap keputusan pembelian produk kecantikan merek Oriflame di Yogyakarta.

Hasil penelitian ini mendukung penelitian Zulaicha dan Irawati (2016), Utomo dan Trisnowati (2017), Sutrisno, Widodo dan Zulianto (2018), bahwa harga berpengaruh signifikan terhadap keputusan pembelian. Hal ini berarti bahwa konsumen produk kecantikan merek Oriflame sangat realistis dalam keputusan pembeliannya. 


\section{KESIMPULAN DAN SARAN}

1. Citra merek berpengaruh signifikan terhadap keputusan pembelian produk kecantikan merek Oriflame.

2. Promosi berpengaruh signifikan terhadap keputusan pembelian produk kecantikan merek Oriflame.

3. Harga berpengaruh signifikan terhadap keputusan pembelian produk kecantikan merek Oriflame. Hal ini berarti bahwa konsumen produk kecantikan merek Oriflame sangat realistis dalam keputusan pembeliannya.

4. Variabel yang mempunyai pengaruh paling besar terhadap keputusan pembelian adalah promosi. Hal ini menunjukkan bahwa kegiatan promosi yang dilakukan efektif berdampak pada keputusan pembelian produk kecantikan merek Oriflame.

Berdasarkan kesimpulan dalam penelitian ini, maka dapat dirumuskan saran yang dapat direkomendasikan terkait dengan permasalahan yang dibahas dalam penelitian ini diantaranya adalah:

1. Perusahaan harus selalu meningkatkan citra merek dengan menghasilkan produk-produk yang berkualitas sesuai dengan kebutuhan pasar.

2. Perusahaan harus lebih meningkatkan usaha promosinya dengan mengefektifkan penggunaan mediamedia promosi.

3. Penentuan tingkat harga harus selalu mempertimbangkan keterjangkauan daya beli konsumen.

4. Dengan sistem yang digunakan Oriflame yaitu sistem direct selling, Oriflame harus memperbanyak perekrutan member, harus memperbanyak seminar seminar tentang peluang bisnis di Oriflame untuk meningkatkan jumlah member Oriflame.

\section{DAFTAR PUSTAKA}

Adisaputro, G. (2010). Manajemen Pemasaran (Analisis Untuk Perancangan Strategi Pemasaran). Yogyakarta: Sekolah Tinggi Ilmu Ekonomi YKPN.

Ahmad, M. (2020). Pengaruh Citra Merek Terhadap Minat Beli Produk Oriflame di Kota Manado. Jurnal Administrasi Bisnis , 25-31.

Alma, B. (2016). Manajemen Pemasaran dan Pemasaran Jasa. Bandung: Alfabeta.

Assael, H. (2001). Consumer Behavior. Edisi Keenam. New York: Thomson Learning.

Devy, S., \& Sinulingga, N. (2018). Pengaruh Harga dan Promosi terhadap Keputusan Pembelian Sepeda Motor pada PT Rotella Persada Mandiri. Journal of Management Science (JMAS), 18-23.

Fure, F., Lapian, J., \& Taroreh, R. (2015). Pengaruh Brand Image, Kualitas Produk dan Harga Terhadap keputusan Pembelian Komsumen di J.CO Manado. Pengaruh Brand Image, Kualitas Produk dan Harga Terhadap keputusan Pembelian Komsumen di J.CO Manado”. Jurnal Riset Ekonomi, Manajemen, Bisnis dan Akuntansi (Jurnal EMBA), 367-277.

Haryono, T. (2012). Manajemen Promosi. Surakarta: UNS Press.

Herlambang, S. (2014). Basic Marketing (Dasar-dasar Marketing) Cara Mudah Memahami Ilmu Pemasaran. Yogyakarta: Gosyeng Publishing.

Kertajaya, H. (2007). Hermawan Kertajaya on Marketing. Edisi Soft Cover. Bandung: Mizan Media Utama.

Khasanah, A., \& Darsin. (2017). Meningkatan Minat Beli Oriflame yang Berdampak pada Kepuasan konsumen. Journal of Management, 1-7.

Kotler, P. (2007). Manajemen Pemasaran, Analisis Perencanaan Pengendalian. Jakarta: Salemba Empat.

Kotler, P. (2009). Manajemen Pemasaran, Edisi ketiga belas Jilid 2. Alih Bahasa Bob Sabran, MM. Jakarta:

Erlangga.

Kotler, P., \& Amstrong, G. (2008). Manajemen Pemasaran Edisi 12 Jilid 2. Jakarta: Indeks.

Kotler, P., \& Keller, K. (2012). Manajemen Pemasaran. Jakarta: Indeks kelompok Gramedia.

Kurniawan, F., Arifin, Z., \& Fanani, D. (2018). Pengaruh Citra Merek Terhadap Keputusan Pembelian (Survei Kepada Para Siswa SMAN 15 Surabaya Kelas XII yang Menggunakan Laptop bermerek Asus). Jurnal Administrasi Bisnis , 75-81.

Permana, D. (2017). Pengaruh Promosi Terhadap Keputusan Pembelian Produk Lantai Kayu dan Pintu PT. Piji di Jawa Timur. Permana D.I. "Pengaruh Promosi Terhadap Keputusan Pembelian Produk LantaiPerforma. Jurnal Manajemen dan Start-Up Bisnis , 116-123.

Prasetijo, R., \& Ihalauw, J. (2005). Perilaku Konsumen. Yogyakarta: Andi.

Sangadji, E., \& Sopiah. (2013). Perilaku Konsumen: Pendekatan Praktis Disertai Himpunan Jurnal Penelitian. Yogyakarta: Andi. 
Sari, D., \& Nuvriasari, A. (2018). Pengaruh Citra Merek, Kualitas Produk dan Harga Terhadap keputusan Pembelian Produk Merek Eiger (Kajian pada Mahasiswa Universitas Mercu Buana Yogyakarta. Jurnal Penelitian Ekonomi dan Bisnis (JPEB), 73-83.

Setiadi, N. (2010). Perilaku Konsumen. Jakarta: Kencana.

Susanti I.Y., Tjahyono E., dan Nasution U.Ch. "Pengaruh Brand Image, Kualitas Produk dan Harga Terhadap Keputusan Pembelian. Jurnal Dinamika Administrasi Bisnis , 1-6.

Sutrisno N.A.R.A., Widodo J., dan Zulianto M. "Pengaruh Bauran Pemasaran Terhadap Keputusan pembelian Produk RM Ayam BakJurnal Pendidikan Ekonomi: Jurnal Ilmiah Ilmu Pendidikan, Ilmu Ekonomi, dan Ilmu Sosial , 259-263.

Swastha, B., \& Handoko, H. (2013). Manajemen Pemasaran Analisa Perilaku Konsumen. Yogyakarta: BPFE UGM.

Tjiptono, F. (2008). Strategi Pemasaran, Edisi Ketiga. Yogyakarta: Andi Offset.

Utomo,L.B., Trisnowati, J. 2017. Analisis Pengaruh Kualitas Produk, Kualitas pelayanan dan Harga terhadap Keputusan Pembeli pada Smooting, Jurnal Penelitian dan Kajian Ilmiah , 14-19.

Wulandari P.P., Widayanto. 2020. "Pengaruh Promosi dan Kualitas Pelayanan terhadap Keputusan Pembelian Mobil Merek Toyota Jurnal Ilmu Administrasi Bisnis , 1-9.

Zulaicha, S., \& Irawati, R. (2016). Pengaruh Produk dan Harga Terhadap keputusan Pembelian Konsumen di Morning Bakery Batam. Inovbiz. Jurnal Inovasi dan Bisnis, 123-136. 